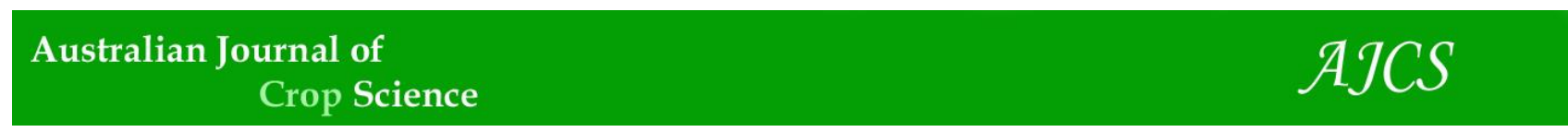

AJCS 12(01):11-15 (2018)

ISSN:1835-2707

doi: 10.21475/ajcs.18.12.01.pne453

\title{
Fruit production and SPAD index of pepper (Capsicum annuum L.) under nitrogen fertilizer doses
}

\section{Flávio da Silva Costa ${ }^{1}$, Antônio Suassuna de Lima ${ }^{2}$, Ivomberg Dourado Magalhães ${ }^{3}$, Lucia Helena Garófalo Chaves $^{2}$, Hugo Orlando Carvallo Guerra ${ }^{2}$}

\author{
${ }^{1}$ Field Education Department, Federal University of Amapá, Av. Intendente Alfredo Pinto, SN, Mazagão, Amapá, \\ Brazil \\ ${ }^{2}$ Technology Center and Natural Resources, Federal University of Campina Grande, Av. Aprigio Veloso, 882, \\ Campina Grande, Paraíba, Brazil \\ ${ }^{3}$ Agricultural Science Center, Federal University of Alagoas, BR-104, km 85, Rio Largo, Alagoas, Brazil
}

*Corresponding author: flaviocostapb@yahoo.com.br

\begin{abstract}
The availability of nitrogen $(\mathrm{N})$ in the soil influences the vegetative development of plants. However, the requirement is usually different between crops. The objective of the present work was to determine the fruit production and the SPAD index of pepper submitted to different amounts of nitrogen applied to the soil and applying this index in the production prognostic of the crop. The experiment was carried out under greenhouse conditions, Paraíba State, Brazil. The treatments were carried out in a completely randomized design, in a $3 \times 5$ factorial experiment, i.e., All Big, Yolo Wonder and Vermelho Samurai-Sais cultivars and five nitrogen fertilization doses $\left(0,33.33,66.67,100\right.$ and $133.33 \mathrm{mg} \mathrm{kg}^{-1}$ soil) with three replicates. At the time of flowering and harvesting of the peppers, the SPAD index was determined, using chlorophyll meter. The total production of fruits per plant was obtained weighing the fruits. Pepper production of all cultivars increased with nitrogen application at 120 days after sowing, using different soil nitrogen applications to reach their maximum productions. The Yolo Wonder cultivar had the maximum production ( $483.7 \mathrm{~g}$ of fruit/plant). The plants that presented SPAD index of 58.5 in the flowering stage showed the maximum fruit yield. The quantification of the SPAD index at the reproductive stages can be used in the prognosis of pepper production.
\end{abstract}

Keywords: Capsicum annuum L., Yolo Wonder, All Big, Vermelho Samuray-Sais, nutrition.

Abbreviations: SPAD_Soil Plant Analysis Development; N_nitrogen; DAS_days after sowing; Ca_calcium; Mg_magnesium; Na_sodium; K_potassium; H_hidrogen; Al_aluminum; P_phosphorus.

Introduction

An adequate adjustment of the nitrogen fertilization of a crop can be achieved by the correct monitoring of the plant nutritional stage and diagnostic (Huett et al., 1997), which involves traditionally the analyses of the nitrogen content in the leaves. However, the use of foliar analyses presents limitations related with the time consumed between collection of material and obtain of results. Among the more recent alternatives with potential of real-time evaluation of plant's nitrogen status, the green intensity analysis of the leaves stands out. It works based on the existence of high correlation between the green intensity and the chlorophyll with the nitrogen content of the leaves. Marquard and Tipton (1987) observed this fact in twelve plant species. Guimarães et al. (1999) also observed this correlation in tomato leaves. Because the nitrogen participates on the synthesis of the structure of the chlorophyll molecules, the supply of nitrogen to the plants increases the chlorophyll content and the green intensity of the plant leaves (Fontes and Araújo, 2007). The Soil Plant Analysis Development (SPAD) index is highly correlated with the chlorophyll content of the leaves (Markwell et al., 1995; Guimarães et al., 1999), which allows estimation of nitrogen status of plant. It identifies field situations, in which the additional nitrogen applications are not necessary. The SPAD indexes obtained from leaves of several plant species showed positive correlation with the nitrogen sufficiency (Blackmer and Schepers, 1995; Shapiro, 1999, Porto et al., 2011; Zuffo et al., 2012), being able to be considered as an adequate index to evaluate the nitrogen status of the plants. The availability and low cost of the green evaluation of plant leaves has become easier with the improvement of portable meters (Guimarães et al., 1999), allowing its application to evaluate the nitrogen status of plants. One of the most known and used meter is the SPAD-502, which offers easy operation in the field being able to use as a tool to undertake nitrogen fertilization decisions.

The SPAD-502 quantitatively evaluates the green leaf intensity, measuring the $650 \mathrm{~nm}$ light streaming, light absorbed by the chlorophyll molecule and the $940 \mathrm{~nm}$ which is not absorbed. With these two values, the equipment calculates the SPAD index. Madakadze et al. (1999), Carreres et al. (2000) and Sandoval-Villa et al. (2000) demonstrated the potentiality of the SPAD-502 to evaluate the response of several plant species to nitrogen application. The pepper (Capsicum annuum L.) belongs to the Solanaceae family originated from America. It has wild species from South of United States to the North of Chile (Filgueira, 2003) and represent one of the most consumed vegetables in Brazil. In 
2006, 77,796 tons were produced in the Northeast of Brazil and 9,006 tons in the Paraiba State, with a total production of 276,767 tons of fruit (IBGE, 2016). One of the factors that majorly influences pepper production is the soil fertility, in which nitrogen $(\mathrm{N})$ content is the second most required element and considered the most important limiting factor for crop production. The excess of $\mathrm{N}$ causes disequilibrium between the growth of the aerial part and the root of the plant, delay in maturation and lower productivity. Its deficiency may also cause immature yellowing in the older leaves, while the new ones remain smalls with a wilting aspect (Filgueira, 2003).

The genetic enhancement is another factor that may contribute to the increases of productivity throughout the development of varieties better adapted to adverse soil and climate conditions, diseases and pests incidence. The existence of many pepper varieties is an advantage. However, selection of a variety to cultivate might be difficult, because it requires knowledge of available options. It is important that the producer knows the behavior of pepper varieties for specific soil and climate conditions in question, aiming optimum crop productivity (Silva et al., 2008).

According to Araújo et al. (2009a) the pepper responds positive and linearly to the increase of nitrogen application to the soil, with gains in diameter, fruit mean weight and number of fruits per plant. Theses authors relate increase of $133 \%$ in the number of fruits in plants that received nitrogen fertilization, when compared with those that did not receive any nitrogen. Others authors (Campos et al., 2008; Araújo et al. 2009a, b; Aragão et al., 2012) also observed the positive effects of the nitrogen fertilization on the productive characteristics of the pepper.

Research efforts to understand the critical SPAD index value in pepper leaves is practically absent in Brazil. This knowledge allows a quick and practical evaluation of the nitrogen nutritional status of the plant, under field condition. The objective of the present work was to determine the fruit production and the SPAD index of three pepper cultivars subjected to different amounts of nitrogen applied to the soil and to evaluate the use of this index on the production prognostic of the crop.

\section{Results and Discussion}

\section{$S P A D$ index}

The SPAD index of chlorophyll of the pepper leaves did not differ significantly $(p>0.05)$ between the cultivars at the flowering and fruit production stages (Table 1). However, it was significantly affected by the soil nitrogen content $(p<0.01)$ at the flowering and harvesting stage of the pepper.

The SPAD index was increased in a non-linear pattern in response to nitrogen increase at the flowering and in a quadratic way at harvest stage, with determination coefficients of 0.89 and 0.99 , respectively (Fig1). The results corroborate with those found by Carvalho et al. (2013) who observed quadratic adjustment for the relation SPAD index and nitrogen application at the collect stage of pepper. According to Carvalho et al. (2013) the SPAD index for a nitrogen application of $100 \mathrm{mg} \mathrm{dm}^{-3}$ soil was 58.55 , similar report to the 56.73 that found in the present study. Grainfenberg et al. (1985) indicated that the nutritional exigencies of pepper are small in the vegetative stage, significantly increasing when the flowering stage is achieved. The similar trend was found for the variation of the cultivars. SPAD indexes under nitrogen fertilization at the flowering and harvest stages indicate the possibility of using the SPAD index for the characterization of the nitrogen status of the pepper.

In the present study, the relation of SPAD index at the collect/harvest stage $(\mathrm{Y})$ with the applied nitrogen to the soil (N) was calculated as $Y=-0.00163 \mathrm{~N}^{2}+0.5580 \mathrm{~N}+17$. Although the nitrogen deficit in the plant is reflected immediately in a low chlorophyll concentration of the leaves, Schroder et al. (2000) indicated that the SPAD indexes are not adequate to predict excess of nitrogen in the plant because under high soil nitrogen availability, part of the nutrient is not converted to produce chlorophyll. According to Godoy et al. (2003) the SPAD index helps in the adjustment of nitrogen soil application, according to the pepper exigencies.

\section{Fruit production}

The pepper cultivars, nitrogen applied to the soil and the interaction among both factors significantly affected the production (Table 2 ).

The total production of pepper increased significantly with the nitrogen application for all the cultivars, being the production of Yolo Wonder > All Big > Vermelho SamuraySais. The total production of Yolo Wonder increased exponentially until the application of $130 \mathrm{mg} \mathrm{N} \mathrm{kg}^{-1}$ soil, with a production of $483.7 \mathrm{~g}$ of fruit/plant. This concentration produced an increment in production of $209 \%$, when compared with the blank ( $0 \mathrm{mg} \mathrm{N} \mathrm{kg}^{-1}$ soil). Similar behavior was observed for the Vermelho Samuray-Sais cultivar with maximum production of $322.59 \mathrm{~g}$ of fruit/plant, which was obtained with a nitrogen application of $94 \mathrm{mg} \mathrm{kg}^{-1}$ soil, corresponding to increase of $191 \%$, when compared with the blank/control. The total production of the All Big cultivar increased linearly with the nitrogen application obtaining a production of $395.43 \mathrm{~g}$ of fruit/plant with an application of $133 \mathrm{mg} \mathrm{N} \mathrm{kg}{ }^{-1}$ soil, corresponding to an increase in production of $79 \%$, compared with the blank (Fig 2).

\section{Pearson correlation}

The SPAD index measured in the plant leaves, at the flowering and collection stage, significantly correlated with the total production with Pearson coefficients fluctuating from moderate to perfect, between 0.6 and 1.0 (Tab 3).

Thus, it is thought that the SPAD index, determined at the flowering stage, could be used to diagnose nitrogen deficiencies in the pepper crop. This indicative value is imperative to maximize the yield of this crop, enabling the detection and correction of the soil nitrogen deficiency before the plant complete the maturation stage of the fruit. 
Table 1. Summary of variance analysis for the SPAD index at flowering and collection of the pepper cultivars under nitrogen fertilization.

\begin{tabular}{|c|c|c|c|}
\hline \multirow{2}{*}{ Source of variation } & \multirow{2}{*}{ DF } & \multicolumn{2}{|c|}{ Mean Square } \\
\hline & & Flowering & Collect \\
\hline Cultivar (CV) & 2 & $20.48^{\text {ns }}$ & $37.69^{\text {ns }}$ \\
\hline Nitrogen $(\mathrm{N})$ & 4 & $208.92 * *$ & $3,025.51^{* *}$ \\
\hline Linear regression & 1 & $745.91^{* *}$ & $11,619.18^{* *}$ \\
\hline Quadratic regression & 1 & $31.19^{\text {ns }}$ & $412.46^{* *}$ \\
\hline Interaction $\mathrm{CV} \times \mathrm{N}$ & 8 & $11.02^{\mathrm{ns}}$ & $10.58^{\mathrm{ns}}$ \\
\hline Error & 30 & 8.47 & 16.745 \\
\hline CV (\%) & & 5.52 & 9.39 \\
\hline
\end{tabular}

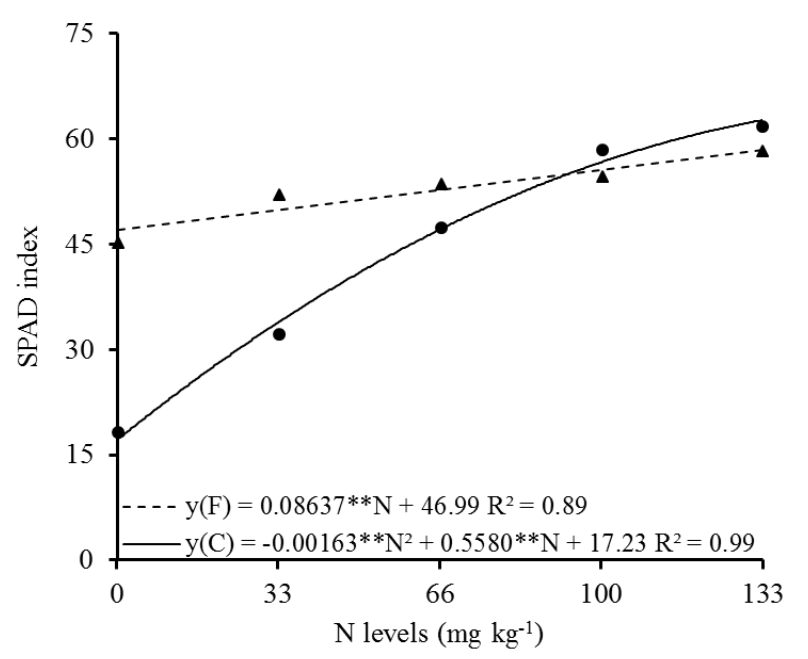

Fig 1. SPAD index of pepper cultivars at flowering, $y(F)$ and collection, $y(C)$ stages for different doses of nitrogen application.

Table 2. Summary of the analyses of variance for the total production of pepper cultivars under different nitrogen applications.

\begin{tabular}{lcc}
\hline Source of variation & DF & Mean Square \\
\hline Cultivar (C) & 2 & $48,081.03^{* *}$ \\
Nitrogen (N) & 4 & $84,775.91^{* *}$ \\
Linear regression & 1 & $287,452.81^{* *}$ \\
Quadratic regression & 1 & $43,996.26^{* *}$ \\
Interaction C X N & 8 & $5,072.26^{* *}$ \\
Error & 30 & 701.01 \\
** and $^{*}$ significant at 1 and 5\% probability, by the F test. & &
\end{tabular}

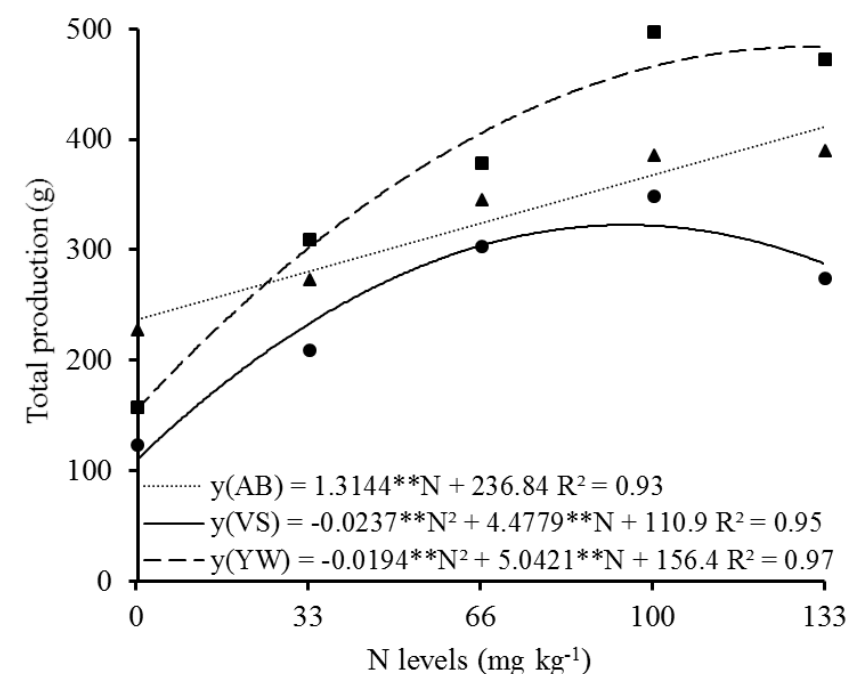

Fig 2. Total production of fruits of the All Big (AB), Vermelho Samurai-Sais (VS) and Yolo Wonder (YW) cultivars, for nitrogen fertilization. 
Table 3. Pearson correlation for the SPAD index (SI) and the total production of pepper cultivars.

\begin{tabular}{lll}
\hline \multirow{2}{*}{ Cultivar } & \multicolumn{2}{c}{ Pearson Correlation } \\
\cline { 2 - 3 } & Flowering & Collect \\
\hline \multirow{2}{*}{ All Big } & $r=0.8^{* *}$ & $r=1.0^{* *}$ \\
& $y=13.270 \mathrm{SI}-363.44$ & $\mathrm{y}=3.623 \mathrm{SI}+172.11$ \\
& $\mathrm{R}^{2}=0.61$ & $\mathrm{R}^{2}=0.91$ \\
\hline \multirow{2}{*}{ Vermelho Samuray-Sais } & $r=0.6^{*}$ & $\mathrm{r}=0.9^{* *}$ \\
& $\mathrm{y}=9.632 \mathrm{SI}-252.68$ & $\mathrm{y}=4.233 \mathrm{SI}+60.245$ \\
& $\mathrm{R}^{2}=0.37$ & $\mathrm{R}^{2}=0.73$ \\
\hline \multirow{3}{*}{ Yolo Wonder } & $\mathrm{r}=0.8^{* *}$ & $\mathrm{r}=0.9^{* *}$ \\
& $\mathrm{y}=15.648 \mathrm{SI}-482.95$ & $\mathrm{y}=6.859 \mathrm{SI}+64.841$ \\
& $\mathrm{R}^{2}=0.58$ & $\mathrm{R}^{2}=0.82$
\end{tabular}

** and ${ }^{*}$, respectively, significant to 1 and $5 \%$ probability by the $\mathrm{F}$ test; $\mathrm{n}=15 ; r$ (Pearson): $0=$ no correlation; 0.1 to $0.3=$ weak; 0.4 to $0.6=$ moderate; 0.7 to $0.9=$ strong; and $1=$ perfect.

The estimate of the total production of fruits per plant $(\mathrm{P})$ as a function of the SPAD index at the flowering stage (SI) can be calculated by the equation $\mathrm{P}=\mathrm{A}$ * SI $-\mathrm{B}$ (Tab 3). However, the SPAD index of 58.5 , the maximum index evidenced by flowering (Fig. 1), was the best correlated with the highest yields obtained by the cultivars of sweet peppers.

\section{Materials and Methods}

\section{Plant material and location of the experiment}

The experiment was carried out under greenhouse conditions at the Agricultural Engineering Department of the Federal University of Campina Grande, located in the municipality of Campina Grande, Paraiba State, Brazil, with

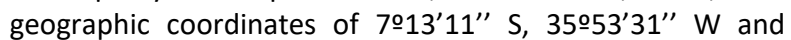
altitude of $547.56 \mathrm{~m}$. The pepper cultivars used were: All Big, Yolo Wonder and Vermelho Samurai-Sais.

\section{Experimental design and treatments}

The treatments were laid out in a completely randomized design, in a $3 \times 5$ factorial scheme (three pepper cultivars and five doses of nitrogen fertilization) with three repetitions, comprising 45 experimental units.

The treatments of nitrogen $(\mathrm{N})$ doses used were $0,33.3$, $66.67,100$, and $133.33 \mathrm{mg} \mathrm{kg}^{-1}$ soil. The $\mathrm{N}$ sources used were urea $(45 \%$ of $\mathrm{N}$ ) being applied $50 \%$ of $\mathrm{N}$ total mixed with the soil and $50 \%$ as cover fertilization 30 days after sowing (DAS). Potassium (potassium chloride) and phosphorus (simple superphosphate) were totally applied in foundation in the amounts of 150 and $300 \mathrm{mg} \mathrm{kg}^{-1}$ of soil, respectively, performed according to the recommendation of Novais et al. (1991).

\section{Conduction of the study}

Each experimental unit consisted of a plastic vase filled with $12 \mathrm{~kg}$ of Luvisol Chromic (Embrapa, 2006) with the following chemical and physical characteristics according to the Embrapa (1997) methodology : $\mathrm{pH}\left(\mathrm{H}_{2} \mathrm{O}\right)=5.8, \mathrm{Ca}=1.29$ $\mathrm{cmol}_{\mathrm{c}} \mathrm{kg}^{-1}, \mathrm{Mg}=1.02 \mathrm{cmol}_{\mathrm{c}} \mathrm{kg}^{-1}, \mathrm{Na}=0.04 \mathrm{cmol}_{\mathrm{c}} \mathrm{kg}^{-1}, \mathrm{~K}=$ $0.16 \mathrm{cmol}_{\mathrm{c}} \mathrm{kg}^{-1}, \mathrm{H}+\mathrm{Al}=1.6 \mathrm{cmol}_{\mathrm{c}} \mathrm{kg}^{-1}, \mathrm{P}=4.5 \mathrm{mg} \mathrm{kg}^{-1}, \mathrm{SOM}=$ $60.3 \mathrm{~g} \mathrm{~kg}^{-1}$, sand $=644 \mathrm{~g} \mathrm{~kg}^{-1}$, silt $=137 \mathrm{~g} \mathrm{~kg}^{-1}$, clay $=219 \mathrm{~g} \mathrm{~kg}^{-}$ ${ }^{1}$, field capacity $=210 \mathrm{~g} \mathrm{~kg}^{-1}$. Five seeds of each cultivar were sown directly in the pots at $2 \mathrm{~cm}$ soil depth. Seven days after sowing (DAS), seedlings were thinned to one plant per pot. The plants were irrigated daily with the volume of water needed to reach the soil field capacity. This volume was calculated daily by the difference of weight between the soil at field capacity and the soil weight at the time of irrigation.

\section{Analyzed variables}

At the time of flowering and harvesting of the peppers, the SPAD index was determined with the use of a chlorophyll meter SPAD-502, in the second fully expanded leaf from the apex to the plant base. The total production of fruits per plant was obtained 120 days after sowing, weighing the fruits throughout a $0.01 \mathrm{~g}$ precision analytic balance.

\section{Statistical analysis}

The experimental data were analyzed by ANOVA. The data were subjected to analysis of variance using F-test at $5 \%$ significance level for all analyzes. In the case of existence of significant effects, regression analyses (linear and quadratic) were proceeded. All the analyses were performed using the statistical software SISVAR (Ferreira, 2011).

\section{Conclusion}

SPAD index and pepper production of all cultivars were increased with nitrogen application, The Yolo Wonder cultivar had the maximum production. The peppers must have a minimum SPAD index of 58.5 in the flowering stage to achieve high fruit yield. The quantification of the SPAD index at the reproductive stages can be used in the prognosis of pepper production.

\section{Acknowledgements}

Thanks to the Federal University of Campina Grande for the availability of the experimental area and the equipment used in the research.

\section{References}

Aragão VF, Fernandes PD, Gomes Filho RR, Carvalho CM, Feitosa HO, Feitosa EO (2012) Produção e eficiência no uso de água do pimentão submetido a diferentes lâminas de irrigação e níveis de nitrogênio. Rev Bras Agric Irrigad. 6:207-216.

Araújo JS, Andrade AP, Ramalho Cl, Azevedo CAV (2009a) Características de frutos de pimentão cultivado em 
ambiente protegido sob doses de nitrogênio via fertirrigação. Rev Bras Eng Agríc Ambient. 13:152-157.

Araújo JS, Andrade AP, Ramalho Cl, Azevedo CAV (2009b) Cultivo do pimentão em condições protegidas sob diferentes doses de nitrogênio via fertirrigação. Rev Bras Eng Agríc Ambient. 13:559-565.

Blackmer TM, Schepers JS (1955) Use of a chlorophyll meter to monitor nitrogen status and schedule fertigation for corn. J Prod Agric. 8:56-60.

Campos VB, Oliveira AP, Cavalcante LF, Prazeres SS (2008) Rendimento do pimentão submetido ao nitrogênio aplicado via água de irrigação em ambiente protegido. Rev Biolog Ciênc Terra. 8:72-79.

Carreres R, Sendra P, Ballesteros R, Cuadra JG (2000) Effects of pre flood nitrogen rate and midseason nitrogen timing on flooded rice. J Agr Sci. 134:379-390.

Carvalho KS, Koetz M, Silva T, Cabral CEA, Nunes AS (2013) Adubação nitrogenada na cultura do pimentão em ambiente protegido. Encic Biosf. 9:49-58.

EMBRAPA (Empresa Brasileira de Pesquisa Agropecuária) (1997) Manual de métodos de análise de solo, 2rd edn. Embrapa, Rio de Janeiro

EMBRAPA (Empresa Brasileira de Pesquisa Agropecuária) (2006) Sistema Brasileiro de Classificação do Solo, 2rd edn. Embrapa, Rio de Janeiro

Ferreira DF (2011) Sisvar: a computer statistical analysis system. Ciênc Agrotec. 35:1039-1042.

Filgueira FAR (2003) Solanáceas: agrotecnologia moderna na produção de tomate, batata, pimentão, pimenta, berinjela e jiló, 1rd edn. UFLA, Lavras

Fontes PCR, Araújo C (2007) Adubação nitrogenada de hortaliças: princípios e práticas com o tomateiro, 1 rd edn. UFV, Viçosa

Godoy LJG, Villas Boas RL, Bull LT (2003) Utilização da medida do clorofilômetro no manejo da adubação nitrogenada em plantas de pimentão. Rev Bras Ciênc Solo. 27:1049-1056.

Grainfenberg A, Petsas S, Lenzi I (1985) Crescita e asportazione degli elementi nutritive nel peperone allevato in serra fredda. Colt Prot. 12:33-38.

Guimarães TG, Fontes PCR, Pereira PRG, Alvarez VVH, Monnerat PH (1999) Teores de clorofila determinados por medidor portátil e sua relação com formas de nitrogênio em folhas de tomateiro cultivado em dois tipos de solo. Bragantia. 58:209-216.
Huett DO, Maier NA, Sparrow LA, Piggottb TJ (1997) Vegetables. In: Reuter DJ, Robinson JB (eds) Plant Analysis: an interpretation manual, 2rd edn. CSIRO, Collingwood

IBGE - Instituto Brasileiro de Geografia e Estatística (2016) Censo Agropecuário 2006: horticultura. Available in: $<$ http://www2.sidra.ibge.gov.br/bda/horti/default.asp?z=t \&o=19\& $i=P>$ Accessed in: December 15, 2016

Madakadze IKA, Madakadze RM, Peterson PR, Coulman BE, Smith DL (1999) Field evaluation of the chlorophyll meter to predict yield and nitrogen concentration of switchgrass. J Plant Nutr. 22:1001-1010.

Markwell J, Osterman J, Mitchell J (1995) Calibration of the Minolta SPAD-502 leaf chlorophyll meter. Photosynth Res. 46:467-472.

Marquard RD, Tipton JL (1987) Relationship between extractable chlorophyll and an in situ method to estimate leaf greenness. Hortscience. 22(6):1327.

Novais RF, Neves JCL, Barros NF (1991) Ensaio em ambiente controlado. In: Oliveira AJ (ed) Métodos de pesquisa em fertilidade do solo, Embrapa, Brasília

Porto MLA, Puiatti, M, Fontes PCR, Cecon PR, Alves JC, Arruda JA (2011) Índice SPAD para o diagnóstico do estado de nitrogênio na cultura da abobrinha. Hortic Bras. 29:311315.

Sandoval-Villa M, Gertal EA, Wood CW (2000) Tomato leaf chlorophyll meter readings as affected by variety, nitrogen form, and nighttime nutrient solution strength. J Plant Nutr. 23:649-661.

Schroder JJ, Neeteson JJ, Oenema O, Struik PC (2000) Does the crop or the soil indicate how to save nitrogen in maize production?: Reviewing the stage of art. Field Crop Res. 66:161-164.

Shapiro CA (1999) Using a chlorophyll meter to manage nitrogen applications to corn with high nitrate irrigation water. Commun Soil Sci Plan. 30:1037-1049.

Silva EA, Mendonça V, Tosta MS, Bardiviesso DM, Oliveira AC, Menegazzo ML (2008) Germinação de sementes e desenvolvimento de mudas de cultivares de pimentão em diferentes substratos. Agrarian. 1:45-54.

Zuffo AM, Andrade FR, Schossler TR, Milhomem DM, Piauilino AC (2012) Eficiência na determinação indireta do nitrogênio foliar a partir do índice SPAD. Encic Biosf. 8:802820. 